\title{
Acute scrotum: differential diagnosis and treatment
}

\author{
Escroto agudo: diagnóstico diferencial e tratamento
}

João Arthur Brunhara Alves Barbosa', Marco Antonio Arap²

Barbosa JABA, Arap M. Acute scrotum: differential diagnosis and treatment / Escroto agudo: diagnóstico diferencial e tratamento. Rev Med (São Paulo). 2018 May-June;97(3):278-82.

ABSTRACT: Acute scrotum (AS) is a clinical syndrome characterized by scrotal pain of acute onset, often accompanied by scrotal swelling and other local and systemic signs and symptoms. It may be the initial presentation of several diseases including testicular torsion, orchitis, epididymitis, hydatid torsion, strangulated hernia and, less frequently, scrotal hematoma and testicular tumor. In the setting of emergency services, physicians should be extremely careful with the possibility of testicular torsion. This condition consists in the torsion of the spermatic cord, leading to an interruption of the testicular blood flow, with ischemia and ultimately necrosis. It is associated with acute severe pain, nausea, absence of the cremasteric reflex, and a high-riding testis. Physical examination may help diagnosis. However, a color Doppler ultrasound of the scrotum is usually required for a definitive diagnosis. Ultrasound will reveal a reduction or no blood flow to the affected testis; surgical treatment is mandatory and should be performed as early as possible. A differential diagnosis is orchiepididymitis. It may be of viral etiology in early childhood and bacterial after the beginning of sexual activity. The most specific sign associated with this condition is the relief of pain after elevation of the testis, known as Prehn's sign. Treatment for bacterial cases requires antibiotics, while cases of viral etiology require only symptomatics. Hydatid torsion, including torsion of appendix testicularis and appendix epididymis may mimic testicular torsion but on ultrasound, blood flow is preserved, and a twisted appendix is often seen. Treatment for this condition consists only in symptomatic control. Testicular torsion should be treated as early as possible, since a delay of 6 hours may result in organ loss. Surgery consists of bilateral orchiopexy in case of a viable testicle and orchiectomy of a necrotic organ, always with fixation of the contralateral testicle.

Keywords: Scrotum; Scrotum/diagnostic imaging; Spermatic cord torsion; Orchitis.
RESUMO: Escroto agudo (EA) é uma síndrome caracterizada por dor escrotal aguda, frequentemente acompanhada por edema escrotal e outros sinais e sintomas locais e sistêmicos. EA pode ser a apresentação inicial de diversas doenças, incluindo torção testicular, orquite, epididimite, torção de hidátide, hérnia inguinal estrangulada e, menos frequentemente, hematoma escrotal e tumor testicular. No contexto de serviços de urgência, o examinador deve ser cauteloso quanto à possibilidade de torção testicular. Essa condição consiste na torção do cordão espermático, levando a interrupção de fluxo sanguíneo, com isquemia e finalmente necrose tecidual. Torção testicular está associada a dor intensa, náusea, alteração do reflexo cremastérico e elevação do testículo, sendo essas variáveis identificadas na história e no exame físico. No entanto, a ultrassonografia escrotal com Doppler frequentemente é necessária para complementação diagnóstica. O exame de ultrassom revela redução ou parada do fluxo sanguíneo para o testículo afetado; nesses casos, o tratamento cirúrgico está indicado e deve ser instituído com a maior brevidade possível, já que um atraso superior a 6 horas pode resultar em perda do órgão. A cirurgia consiste em orquidopexia bilateral em caso de testículo viável; nos casos em que o testículo sofre necrose, este deve ser removido, porém o testículo contralateral deve ser fixado para prevenir novos episódios. Um diagnóstico diferencial da torção tesiticular é a orquiepididimite, que pode ser de etiologia viral na infância e frequentemente bacteriana após o início da atividade sexual. O sinal mais específico para o diagnóstico de orquiepididimite é o alívio da dor com a elevação manual do testículo, conhecido como sinal de Prehn. O tratamento da doença bacteriana requer antibióticos, enquanto os casos de etiologia viral requerem somente sintomáticos. A torção de hidátide, que inclui torção do apêndice testicular ou do apêndice epididimal, pode simular o quadro clínico da torção testicular, porém ao ultrassom com Doppler, o fluxo sanguíneo está preservado e um apêndice torcido frequentemente é encontrado. $\mathrm{O}$ tratamento para essa condição requer somente controle sintomático.

Descritores: Escroto; Escroto/diagnóstico por imagem; Torção do cordão espermático; Orquite.

1.Divisão de Urologia, Hospital das Clínicas HCFMUSP, Faculdade de Medicina, Universidade de Sao Paulo, Sao Paulo, SP, BR. Médico residente. ORCID: https://orcid.org/0000-0001-9646-8588. Email: jbrunhara@gmail.com.

2. Divisao de Urologia, Hospital das Clinicas HCFMUSP, Faculdade de Medicina, Universidade de Sao Paulo, Sao Paulo, SP, BR. Chefe do Setor de Pronto Socorro. Hospital Sírio Libanês. ORCID: https://orcid.org/0000-0002-2577-119X. Email: marcoarap@hotmail.com.

Endereço para correspondência: João Arthur B. A. Barbosa. Instituto Central, Hospital das Clínicas da Faculdade de Medicina da Universidade de São Paulo, Urologia - $7^{\circ}$ andar. Av. Dr. Enéas de Carvalho Aguiar, 255. Cerqueira César. São Paulo, SP, BR. CEP: 05403-000. 


\section{INTRODUCTION}

A cute scrotum (AS) is a clinical syndrome characterized by scrotal pain of acute onset, often accompanied by scrotal swelling and other local and systemic signs and symptoms. It may be the initial presentation of several conditions of varying severity and morbidity. Physicians should always be concerned about the diagnosis of Testicular Torsion (TT), a condition which accounts for up to $25 \%$ of cases of AS and may lead to testicular loss if not treated within 6 hours after pain onset. Therefore, AS should be treated as an emergency until diagnosis is made, and warrants high priority and expedited diagnostic work-up in every emergency service ${ }^{1}$. This is particularly true in the pediatric population, which accounts for the majority of TT cases.

Differential diagnosis include testicular torsion, orchitis, epididymitis, hydatid torsion, incarcerated inguinal hernia and, less frequently, scrotal hematoma, acute idiopathic scrotal edema, testicular tumor and Henoch-Schönlein purpura ${ }^{2}$. Cases of spontaneous hematoma are rare, and clinical history often clarifies the existence of a recent local trauma. Testicular tumor is also not frequent in the setting of AS since it is usually a painless, growing scrotal mass that may eventually present with acute pain in the event of rupture or bleeding. Henoch-Schönlein purpura is a rare systemic vasculitis mediated by immune complexes; children with this condition will often present will plaquetopenia and generalized purpura.

Diagnostic work-up includes a focused evaluation on clinical history, careful physical examination in search of specific signs and imaging studies. In selected cases, in which TT is highy suspected, surgical exploration may be indicated without imaging studies, especially if the study will delay surgical exploration. Although scrotal scintigraphy and other tests have been used in the past, Doppler Ultrasonography of the Scrotum (DUS) is the most timely efficient exam available to date, with very good sensitivity and specificity ${ }^{3}$. In this review, we will outline key aspects in diagnostic work-up, specific features and treatment choices of the main conditions that may present as AS.

\section{Diagnostic evaluation}

Diagnostic work-up for AS begins with key points in clinical history. Patient age may be suggestive of some diagnoses; incidence of TT decreases after childhood and adolescence; conversely, among sexually active subjects, bacterial orchitis and epididymitis become more frequent, being most frequent in the third decade, although a late peak after 50 years may also occur ${ }^{4,5}$. Duration and intensity of the pain must also be recorded; pain associated with TT is usually acute, very intense and urges early medical attention; conversely, orchitis may be associated with a longer duration of symptoms ${ }^{6}$. The patient should also be evaluated in relation to the existence of previous testicular pathology, surgery, or previous treated or untreated inguinal hernia. In addition, the presence of nausea or vomiting may also be a predictor of TT.

Physical examination of the scrotum includes several specific signs that may suggest one particular diagnosis $\mathrm{s}^{7,8}$. Scrotal swelling is common to several diagnoses, including TT and epididymitis, and does not suggest one specific disease. Testicular torsion is associated with the absence of the cremasteric reflex, and a high-riding testis ${ }^{9}$. It should be noted that the cremasteric reflex may not be easy to elicit. Although its absence does not lead to a conclusive diagnosis of TT, the presence of a normal reflex has a high negative predictive value. Orchitis and epididymitis are characterized by a painful swelling of the scrotum. Manual elevation of the affected testis toward the abdomen may result in pain relief, which is known as Prehn's sign. Again, this maneuver can be exceedingly difficult to perform and to interpret in the pediatric population ${ }^{2}$. Hydatid torsion may present with a blue dot sign, seen as a bruise in the scrotum, cranial to the testis, with a palpable structure corresponding to the twisted hydatid.

Doppler Ultrasonography of the Scrotum (DUS) is currently the most time efficient and reliable imaging study for complementary evaluation of acute scrotum ${ }^{10}$. DUS compatible with TT reveals severe reduction or absence of testicular blood flow and signs of a twisted spermatic cord. Negative and Positive predictive values for evaluation of TT have been reported to be as high as $100 \%{ }^{11}$. However, ultrasound is associated with high inter-examiner variability. Furthermore, several factors influence test results, including radiologist experience, availability of a high-resolution ultrasound and availability of the Doppler function ${ }^{12}$. Hence, although DUS may elicit excellent results, it is still subject to variability and imperfection.

If suspicion for TT raised by history and physical examination is high, the physician may suggest surgical exploration without additional imaging. However, the use of DUS has become nearly mandatory ${ }^{13}$. Yet, DUS is not always readily available and may result in delay of diagnosis and treatment. With the aim of reducing delay and unnecessary exams, a scoring system for the diagnosis of TT with only clinical variables has been developed $^{6}$. The Testicular Work-up for Ischemia and Suspected Torsion (TWIST) Score includes 5 variables, being edema/erythema and a hard mass on palpation worth 2 points each; absence of cremasteric reflex, nausea or vomiting and a high-riding testis are worth 1 point each. If the score is lower than 2 points, there is very low risk for TT; conversely, with a score of 5 or above, there is high suspicion for TT and surgery should be indicated ${ }^{6}$. 
The TWIST scoring system has been validated in at least 2 independent cohorts and could be a valuable tool in expediting surgical treatment for $\mathrm{TT}^{14,15}$ (Table 1).

Table 1. Variables and risk stratification according to the Testicular Work-up for Ischemia and Suspected Torsion (TWIST) Score. Probabilities based on studies by Barbosa et al. ${ }^{6}$ and Sheth et al. ${ }^{14}$

\begin{tabular}{l|l}
\hline Variable & \\
\hline Nausea/Vomiting & 1 point \\
\hline Absent cremasteric reflex & 1 point \\
\hline High-riding testis & 1 point \\
\hline Hard mass to palpation & 2 points \\
\hline Testicular edema/erythema & 2 points \\
\hline Risk categories for Testicular Torsion \\
\hline $0-2$ points & Low Risk (0-4\%) \\
\hline 3-4 points & Intermediate Risk (18-23\%) \\
\hline 5-7 points & High Risk (86-100\%) \\
\hline
\end{tabular}

\section{Testicular Torsion}

The incidence of TT is 3.8 cases in every 100,000 males younger than 18 years of age ${ }^{16}$. Torsion of the spermatic cord results in reduction or interruption of the blood flow to the testis. After 6 to 8 hours, ischemia and necrosis follow, often resulting in orchiectomy after this time point. Neonatal and perinatal torsion should be interpreted as a different condition; in these cases, an extravaginal torsion involves torsion not only of the testis but also of the spermatic cord and the processus vaginalis. Salvage rate in these cases is extremely low ${ }^{17}$. Conversely, in adolescents, the most common form of TT is intravaginal. The bell-clapper deformity, which is an abnormally high implantation of the tunica vaginalis to the testis, results in increased mobility of the testis and higher risk for $\mathrm{TT}^{18}$. The diagnosis of $\mathrm{TT}$ relies on signs, symptoms and imaging studies discussed above. There should be attention to one specific condition called intermittent torsion: the testis may spontaneously detorse and present with a history of intense pain with subsequent relief; on Ultrasound, the testis is usually swollen with preserved blood flow. Similarly, manual detorsion of the testis may be performed when surgery is not readily available. These cases should receive surgical treatment nevertheless, since torsion may reccur ${ }^{19}$.

Treatment for TT is surgical exploration. Through a scrotal incision, the testis is exposed and detorsed. Decision on viability of the testis occurs intraoperatively; it depends on the visual aspect of the testis after detorsion. If a testicle remains pale, dark and necrotic for at least 5 minutes after detorsion, it should be removed at this time. Conversely, if it is visually viable, it should undergo orchiopexy. Of note, orchiopexy of the contralateral unaffected testis should always be done in the same procedure. Studies have shown that hormonal levels following TT remain within normal parameters. Sperm alterations are more frequent among patients who undergo orchiopexy than orchiectomy, presumably due to the contribution of an abnormal testis and the production of antisperm antibodies. However, in both groups sperm concentration is inferior to healthy controls ${ }^{20}$.

\section{Epididymitis and Orchitis}

Epididymitis and Orchitis are inflammatory processes of the epididymis and testis, respectively. In the context of AS, these are often infectious processes, either of viral or bacterial origin. Pain is usually less intense and duration more insidious than for TT. In children, cases of viral etiology predominate, especially in mumps orchitis. Patients may have presented earlier with parotitis and should have antibody investigation performed. Conversely, bacterial infection in patients after adolescence is more frequent, after the beginning of sexual activity ${ }^{21}$. In young men, sexually transmited agents may occur, such as Chlamydia trachomatis. Of note, in elderly patients, uropathogens such as Escherichia coli are commonly found ${ }^{22}$.

Physical examination reveals edema, erythema and tenderness of the scrotum; cremasteric reflex is normal, as well as the position of the testicle; elevation of the testicle may relieve pain (Prehn's sign). DUS reveals intense edema and augmented vascularization; blood flow through the spermatic cord is present. Urinalysis should be performed, particularly among patients with epidemiological risk for bacterial infection; in these cases, a urethral swab should also be collected. In young patients, after sample collection, empirical treatment must include coverage for $C$. trachomatis; in this setting, fluoroquinolones such as Levofloxacin should be the first choice for their spectrum and tissue penetration. If presence of $C$. trachomatis is documented, treatment should be continued for 2 additional weeks with Doxycycline $200 \mathrm{mg} /$ day. In this case, partners should be treated as well, and general serological tests for sexually transmitted diseases should be performed. Elderly and sexually inactive patients should be treated with usual drugs for urinary tract infection until urine culture is available.

Treatment for these infections should also take into consideration symptomatic relief and local care. Apart from simple analgesia, bed rest, up-positioning of the testes and local cooling are indicated; anti-inflammatory drugs may also be useful for pain control. Due to the possibility of permanent occlusion of epididymal ducts 
and fertility impairment, one may consider for young patients the use of methylprednisolone at $40 \mathrm{mg}$ per day, reducing the dose by half every second day ${ }^{22}$.

\section{Hydatid Torsion}

Hydatid torsion includes torsion and ischemia of small appendages of the testis and epididymis. The appendix testicularis is a remnant of the Mullerian duct and the appendix epididymis is a remnant of the Wolffian duct $^{23}$. Pain may be acute and intense, resembling that of TT. On examination, pain may be localized cranial to the testis. However, especially in children, this may be a difficult information to obtain. The most specific sign associated with hydatid torsion is the blue dot sign, a small scrotal bruise associated with a palpable tender structure. DUS may reveal a twisted, non-perfused hydatid and frequently an associated edema of the epididymis. Treatment involves symptomatic control, bed rest and local care. Surgery is rarely needed, as there is no need to preserve the hydatid and pain is usually controllable.

\section{Future perspectives and controversy}

Future investigations of acute scrotum should look into possibilities for a faster diagnosis and also strategies to raise the rate of testicular salvage ${ }^{24}$. There is controversy and debate about the necessity of DUS in all cases of AS before surgery. While some authors advocate imaging studies in all cases ${ }^{25}$, others have demonstrated a growing effort into abbreviating diagnosis with findings from physical examination ${ }^{6,14,24}$. Diagnostic tests with limited availability and requiring longer time and even sedation have been performed and tried in the past, but have seen their use decreased due to the inadequacy of such tests in the emergency context. Examples of such exams are scrotal scintigraphy, which provides elevated sensitivity and specificity (higher than 90\%) but often requiring sedation and taking longer than desired and magnetic resonance, which has been tried in experimental character $^{26}$.

In particular, the use of the TWIST score could be particularly useful in this setting, especially when used by physicians with no urological training, so as to triage the patient directly for urological evaluation and eventual surgery ${ }^{14}$.

Also of note, the use of Transscrotal Near Infrared Spectroscopy (NIRS) is another possibility for future use in the diagnosis of testicular torsion ${ }^{27}$. This technology aims to determine the oxygen saturation of tissues with a portable device that allows quick results. A twisted testis is expected to present interruption of blood flow and ischemia, thus resulting in lower values of oxygen saturation. Animal models presented promising results in detecting testicular torsion ${ }^{28,29}$. However, the largest trial to date, looking at the use of NIRS in pediatric acute scrotum failed to demonstrate reliable results ${ }^{30}$. It is not clear whether technological improvements of this device may lead to more consistent results.

Another source of potential improvement in testicular salvage rate is the intraoperative management of the twisted testis, in particular in cases with doubtful viability. Some authors have advocated that, following ischemia and edema, a testicular compartimental syndrome occurs, resulting in further impairment to perfusion and viability. In this setting, an incision of the tunica albuginea, described as a testicular fasciotomy after detorsion, has been hypothesized to increase the rate of testicular salvage ${ }^{31}$. In the largest series to date reporting on this procedure, orchiectomy rate among patients undergoing fasciotomy was $15 \%$ as compared to $35 \%$ among those who did not ${ }^{32}$.

\section{CONCLUSION}

Acute scrotum is an emergency, since the presence of testicular torsion accounts for up to $25 \%$ of cases and may cause permanent damage and organ loss if not immediately treated. Differential diagnosis includes orchitis, epididymitis, hydatid torsion, inguinal hernia and other less frequent conditions. Careful history and physical examination may be suggestive of the diagnosis. Although no single sign is pathognomonic of TT, the cremasteric reflex is perhaps the most useful sign in physical examination. Doppler ultrasound of the scrotum is frequently used for a conclusive diagnosis and before surgery. While definitive treatment of TT is always surgical, orchiepididymitis and hydatid torsion should be clinically managed with medication and local care. Whenever diagnosis is uncertain or inconclusive per clinical and radiological investigation, surgical exploration should be indicated.

\section{REFERENCES}

1. DaJusta D, Granberg CF, Villanueva C, Baker LA. Contemporary review of testicular torsion: new concepts, emerging technologies and potential therapeutics. J Pediatr Urol. 2013;9(6):10.1016/j.jpurol.2012.08.012. doi: 10.1016/j.jpurol.2012.08.012

2. Günther P, Rübben I. The acute scrotum in childhood and adolescence. Dtsch Ärztebl Int. 2012;109(25):449-58. doi: 10.3238/arztebl.2012.0449.

3. Agrawal AM, Tripathi PS, Shankhwar A, Naveen C. Role of ultrasound with color Doppler in acute scrotum management. J Fam Med Primary Care. 2014;3(4):409-12. doi:10.4103/2249-4863.148130.

4. Mittemeyer BT, Lennox KW, Borski AA. Epididymitis: a review of 610 cases J Urol. 1966;95(3):390-2. 
5. Kaver I, Matzkin H, Braf ZF. Epididymoorchitis: a retrospective study of 121 patients J Fam Pract. 1990;30(5):548-52.

6. Barbosa JA, Tiseo BC, Barayan GA, Rosman BM, Torricelli FC, Passerotti CC, Srougi M, Retik AB, Nguyen HT. Development and initial validation of a scoring system to diagnose testicular torsion in children. J Urol. 2013;189:1859-64. doi: 10.1016/j.juro.2012.10.056.

7. Ciftci AO, Senocak ME, Tanyel FC, Büyükpamukçu N. Clinical predictors for differential diagnosis of acute scrotum. Eur J Pediatr Surg. 2004;14(5):333-8. doi: $10.1055 / \mathrm{s}-2004-821210$

8. Beni-Israel T, Goldman M, Bar Chaim S, Kozer E. Clinical predictors for testicular torsion as seen in the pediatric ED. Am J Emerg Med. 2010;28(7):786-9. doi: 10.1016/j. ajem.2009.03.025.

9. Nelson CP, Williams JF, Bloom DA. The cremasteric reflex: a useful but imperfect sign in testicular torsion. J Pediatr Surg. 2003;38(8):1248-9. https://doi.org/10.1016/S00223468(03)00280-X

10. Yazbeck S, Patriquin H. Accuracy of Doppler sonography in the evaluation of acute conditions of the scrotum in children. J Pediatr Surg. 1994;29:1270-2.

11. Agrawal AM, Tripathi PS, Shankhwar A, Naveen C. Role of ultrasound with color Doppler in acute scrotum management. J Fam Med Primary Care. 2014;3(4):409-12. doi:10.4103/2249-4863.148130.

12. Kalfa N, Veyrac C, Lopez M, Lopez C, Maurel A, Kaselas C, Sibai S, Arena F, Vaos G, Bréaud J, Merrot T, Kalfa D, Khochman I, Mironescu A, Minaev S, Avérous M, Galifer RB. Multicenter assessment of ultrasound of the spermatic cord in children with acute scrotum. J Urol. 2007;177:297301. doi: $10.1016 /$ j.juro.2006.08.128.

13. Schmitz D, Safranek S. Clinical inquiries. How useful is a physical exam in diagnosing testicular torsion? J Fam Pract. 2009;58(8):433-4.

14. Sheth KR, Keays M, Grimsby GM, Granberg CF, Menon VS, DaJusta DG, Ostrov L, Hill M, Sanchez E, Kuppermann D, Harrison CB, Jacobs MA, Huang R, Burgu B, Hennes $\mathrm{H}$, Schlomer BJ, Baker LA. Diagnosing testicular torsion before urological consultation and imaging: validation of the TWIST score. J Urol. 2016;195:1870-6. doi: 10.1016/j. juro.2016.01.101.

15. Frohlich LC, Paydar-Darian N, Cilento BG Jr, Lee LK.Prospective validation of clinical score for males presenting with an acute scrotum. Acad Emerg Med. 2017;24(12):1474-82. doi: 10.1111/acem.13295.

16. Zhao LC, Lautz TB, Meeks JJ, Maizels M. Pediatric testicular torsion epidemiology using a national database: incidence, risk of orchiectomy and possible measures toward improving the quality of care. J Urol. 2011;186(5):2009-13. doi: 10.1016/j.juro.2011.07.024.

17. Nandi B, Murphy FL. Neonatal testicular torsion: a systematic literature review. Pediatr Surg Int. 2011;27(10):1037-40. doi: 10.1007/s00383-011-2945-x.

18. Favorito LA, Cavalcante AG, Costa WS. Anatomic aspects of epididymis and tunica vaginalis in patients with testicular torsion. Int Braz J Urol. 2004;30(5):420-4. Available from: http://www.brazjurol.com.br/september_october_2004/ Favorito_ing_420_424.htm.
19. Stillwell TJ, Kramer SA. Intermittent testicular torsion. Pediatrics. 1986;77(6):908-11. Available from: http:// pediatrics.aappublications.org/content/pediatrics/77/6/908. full.pdf.

20. Arap MA, Vicentini FC, Cocuzza M, Hallak J, Athayde K, Lucon AM, Arap S, Srougi M. Late hormonal levels, semen parameters, and presence of antisperm antibodies in patients treated for testicular torsion. J Androl. 2007;28(4):528-32. doi: 10.2164/jandrol.106.002097.

21. Somekh E, Gorenstein A, Serour F. Acute epididymitis in boys: evidence of a post-infectious etiology. J Urol. 2004;171:391-4. doi: 10.1097/01.ju.0000102160.55494.1f.

22. EAU Guidelines. Edn. presented at the EAU Annual Congress Copenhagen 2018. ISBN 978-94-92671-01-1.

23. Sellars ME, Sidhu PS. Ultrasound appearance of testicular appendages: pictorial review. Eur Radiol. 2003;13:127-35. doi: 10.1007/s00330-002-1387-1.

24. Barbosa JA, Denes FT, Nguyen HT. Testicular torsion-can we improve the management of acute scrotum? J Urol. 2016;195(6):1650-1. doi: 10.1016/j.juro.2016.03.066.

25. Yazbeck, S. and Patriquin, H.B. Accuracy of Doppler sonography in the evaluation of acute conditions of the scrotum in children. J Pediatr Surg. 1994;29:1270-2. https:// doi.org/10.1016/0022-3468(94)90822-2.

26. Joyce JM, Grossman SJ. Scrotal scintigraphy in testicular torsion. Emerg Med Clin North Am. 1992;10(1):93-102.

27. Burgu B, Aydogdu O, Huang R, Soygur T, Yaman O, Baker L. Pilot feasibility study of transscrotal near infrared spectroscopy in the evaluation of adult acute scrotum. J Urol. 2013;190:124-9. doi: 10.1016/j.juro.2013.01.080.

28. Aydogdu O, Burgu B, Gocun PU, Ozden E, Yaman O, Soygur T, Dursun A, Aydos K. Near infrared spectroscopy to diagnose experimental testicular torsion: comparison with Doppler ultrasound and immunohistochemical correlation of tissue oxygenation and viability. J Urol 2012;187:744-50. doi: 10.1016/j.juro.2011.09.145.

29. Capraro GA, Mader TJ, Coughlin BF, Lovewell C, St Louis MR, Tirabassi M, Wadie G, Smithline HA. Feasibility of using near-infrared spectroscopy to diagnose testicular torsion: an experimental study in sheep. Ann Emerg Med. 2007;49:520-5. doi: 10.1016/j.annemergmed.2006.06.041.

30. Schlomer BJ, Keays MA, Grimsby GM. Transscrotal near infrared spectroscopy as a diagnostic test for testis torsion in pediatric acute scrotum: a prospective comparison to Gold Standard Diagnostic Test Study. J Urol. 2017;198(3):694701. doi: 10.1016/j.juro.2017.03.134.

31. Kutikov A, Casale P, White MA, Meyer WA, Chang A, Gosalbez R, Canning DA. Testicular compartment syndrome: a new approach to conceptualizing and managing testicular torsion. Urology. 2008t;72(4):786-9. doi: 10.1016/j.urology.2008.03.031.

32. Figueroa V, Pippi Salle JL, Braga LH, Romao R, Koyle MA, Bägli DJ, Lorenzo AJ. Comparative analysis of detorsion alone versus detorsion and tunica albuginea decompression (fasciotomy) with tunica vaginalis flap coverage in the surgical management of prolonged testicular ischemia. J Urol. 2012;188(4 Suppl):1417-22. doi: 10.1016/j. juro.2012.02.017.

Submitted for publication: Apr 02, 2018

Accepted in: May 15, 2018 